\title{
THE EFFECT OF SEED SIZE AND DEPTH OF SEEDING ON THE EMERGENCE OF GRASSLAND PLANTS
}

\author{
K. MultamäKi \\ Agricultural Research Centre, Department of Plant Breeding, Jokioinen
}

Received November 22, 1961

The seeding of grasslands in Finland fails relatively often owing to the difficult growing conditions for the young seedlings. As a result, the stands are in many cases rather thin and must sometimes be ploughed up without giving any yield at all.

One of the factors hampering the initial growth and development of grassland plants is unsuitable sowing. Thus, for instance, a considerable proportion of the seed may be sown at too great a depth, which prevents the seedlings from emerging. On the other hand, the seeds scattered upon the soil surface will also meet difficulties in their germination stage, especially in dry periods. Hence, a valuable characteristic for a grassland plant seedling would be the ability to surmount the various obstacles arising from deficient seeding measures.

The object of the present investigation is to study the emergence capacity of some grassland plants, the majority of which are grown extensively in Finland. For this purpose, seeds of the plants to be studied were sown on soil surface as well as at different depths. The influence of seed size in this connexion was examined, too. All the studies concerned were carried out in the greenhouse. The soil used as substrata in these experiments was heavy clay, representing the valuable arable soil type occurring fairly commonly, especially in Southwest Finland.

\section{Review of literature}

MURPHY and ARNY (4) found depth of planting to be the most important factor determining the total emergence of seedlings of various grasses and legumes. The seed weight showed a significant positive correlation with the total emergence. In alfalfa, ERICKSON (1) observed that both germination and vigour of the seedlings were directly correlated with seed size. Seedling vigour was inversely related to the depth of seeding. ROGLER (5) established highly significant differences in total 
seedling emergence for depths, weights, and the interaction of depths and weights in crested wheatgrass. McKenzie et al. (3) and LuecK et al. (2), found that the maximum depth of seeding varied considerably according to the grass species and varieties studied.

\section{Material and methods}

Few of the plant species and none of the varieties tested in these experiments, however, are used in grassland cultivation in Finland. A corresponding experiment with plant material more familiar in Finnish conditions was thus considered appropriate.

The following plant species and strains were included in the experiment:

$\begin{array}{lll}\text { I red clover, diploid } & \text { Tammisto, Finland } \\ \text { II } & \text { tetraploid } & \text { Jo TPA 1 } \\ \text { III alsike } & \text { diploid } & \text { Jo AA 10 } \\ \text { IV } & & \text { Jo TAA 4 } \\ \text { V white } & \text { Morsø, Denmark } \\ \text { VI timothy } & \text { Paavo, Jokioinen } \\ \text { VII meadow fescue } & \text { Pajbjerg II, Denmark } \\ \text { VIII cocksfoot } & \text { Viris, Sweden } \\ \text { IX perennial rye-grass } & \text { Foreign commercial seed } \\ \mathrm{X} \text { Italian } & \end{array}$

The strains for the experiment were selected from the breeding material of the Department of Plant Breeding at Jokioinen (marked Jo) as well as from commercial varieties and seed. From each of the strains 3 or 4 seed-size classes were separated by means of screening and hand sorting. The weight of the seeds was determined by taking an average of three separate lots of 200 seeds, All test seeds were treated with malathion preparation immediately before sowing. The normal germination capacity was analyzed in the ordinary way from 4 samples of 100 seeds each.

For each of the tetraploid clovers and for timothy, four seed-size classes were taken; in another eight strains only three size classes were separated. The 1000seed weights in grams on the different seed-size classes of the eleven grassland, plants studied were as follows:

\begin{tabular}{|c|c|c|c|c|c|}
\hline & & Small & $\begin{array}{l}\text { Medium- } \\
\text { sized }\end{array}$ & Large & $\begin{array}{l}\text { Super- } \\
\text { sized }\end{array}$ \\
\hline I & Red clover, & 1.100 & 1.700 & 2.233 & - \\
\hline II & tetraploid & 1.300 & 1.700 & 2.240 & 3.100 \\
\hline III & Alsike clover, diploid & 0.550 & 0.691 & 0.917 & - \\
\hline IV & tetraploid & 0.660 & 0.700 & 0.912 & 1.500 \\
\hline V & White clover & 0.483 & 0.626 & 0.933 & - \\
\hline VI & Timothy & 0.303 & 0.422 & 0.640 & 0.861 \\
\hline VII & Meadow fescue & 1.133 & 1.775 & 2.433 & - \\
\hline VIII & Cocksfoot & 0.583 & 0.783 & 1.066 & - \\
\hline IX & Perennial rye-grass & 1.425 & 1.758 & 2.275 & - \\
\hline $\mathrm{x}$ & Italian & 1.216 & 1.790 & 2.608 & - \\
\hline $\mathrm{XI}$ & Red fescue & 0.950 & 1.163 & 1.416 & - \\
\hline
\end{tabular}




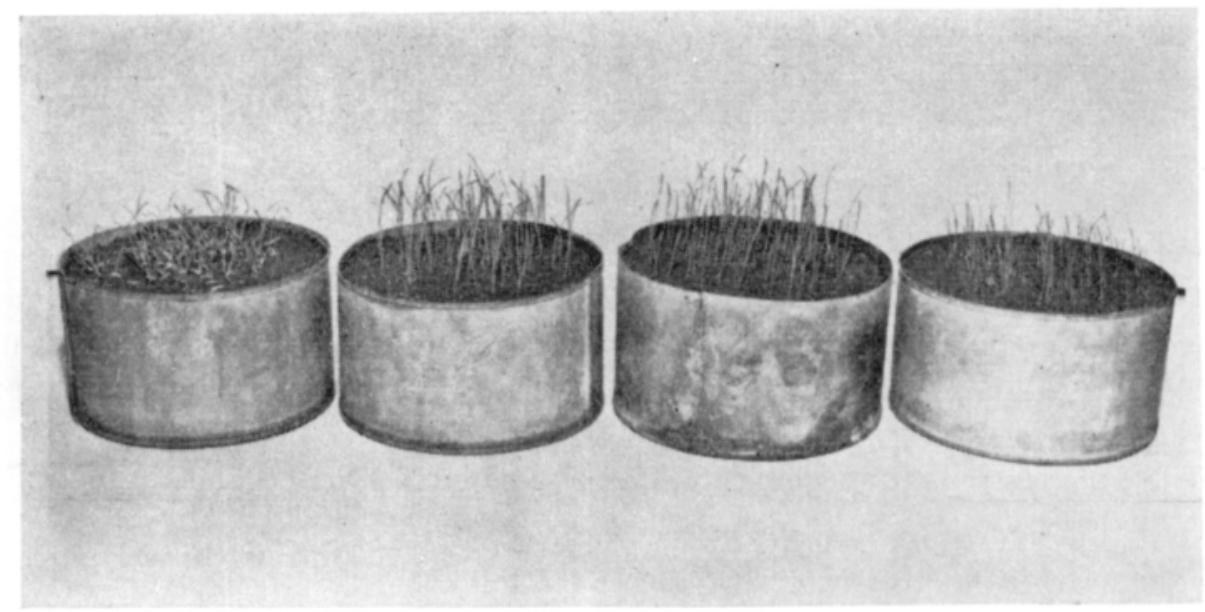

Figure 1. Emergence of the large-sized seeds of Italian rye-grass from surface, 1-cm, 2.5-cm, and 4-cm depths, 7 days after seeding. Photo by O. INKILÄ.

The heavy clay soil selected for this study was taken from the surface 20 centimetres of the experimental field at Jokioinen. The soil concerned contained $4-5 \%$ organic matter, its degree of acidity varying between $\mathrm{pH} 5.5-5.9$. Before use, the soil was air-dried and sieved in order to remove lumps.

Seeding was done in cylindrical dishes measuring $15 \mathrm{~cm}$ in diameter and $9 \mathrm{~cm}$ in height (Figure 1). The depths of planting used in this study were as follows: surface, $1 \mathrm{~cm}, 2.5 \mathrm{~cm}, 4 \mathrm{~cm}$, and $7 \mathrm{~cm}$. The planting depths were determined accurately by means of wooden soil levellers. After seeding, the soil was kept at optimum moisture in order to promote germination and emergence of the seedlings.

The dishes were kept in the greenhouse, where the temperature was maintained at $+18^{\circ}$ to $+25^{\circ} \mathrm{C}$ by day and at $+14^{\circ}$ to $+18^{\circ} \mathrm{C}$ at night.

The germination capacity of the different seed-size classes proved to be very high, varying between 96 and 100 per cent. In each dish 100 seeds were sown. Every seed-size class being planted at five depths with four replicates for each, was thus grown in 20 dishes in all. Notes on the emergence were recorded daily until no further seedlings appeared.

\section{Experimental results}

In order to gain an idea of the rate of emergence of the different strains investigated, the average emergence of the medium-sized seeds from the 1 -cm depth was calculated for three-day periods. The results are shown graphically in Figure 2. It appears that, on the whole, the legume seedlings $(\mathrm{I}-\mathrm{V})$ began to emerge more rapidly than the grass seedlings (VI-XI). In addition, the legumes often attained total emergence over a shorter period of time than the grasses.

Between the individual strains some great differences are to be seen with 
Number of

seedlings

emerged out of

100 seeds

sown:

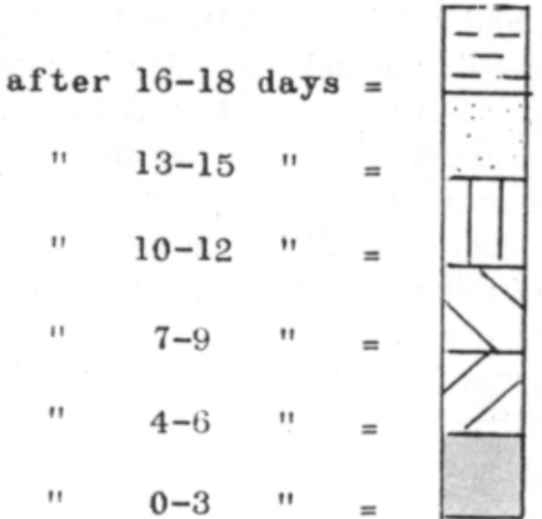

90

80
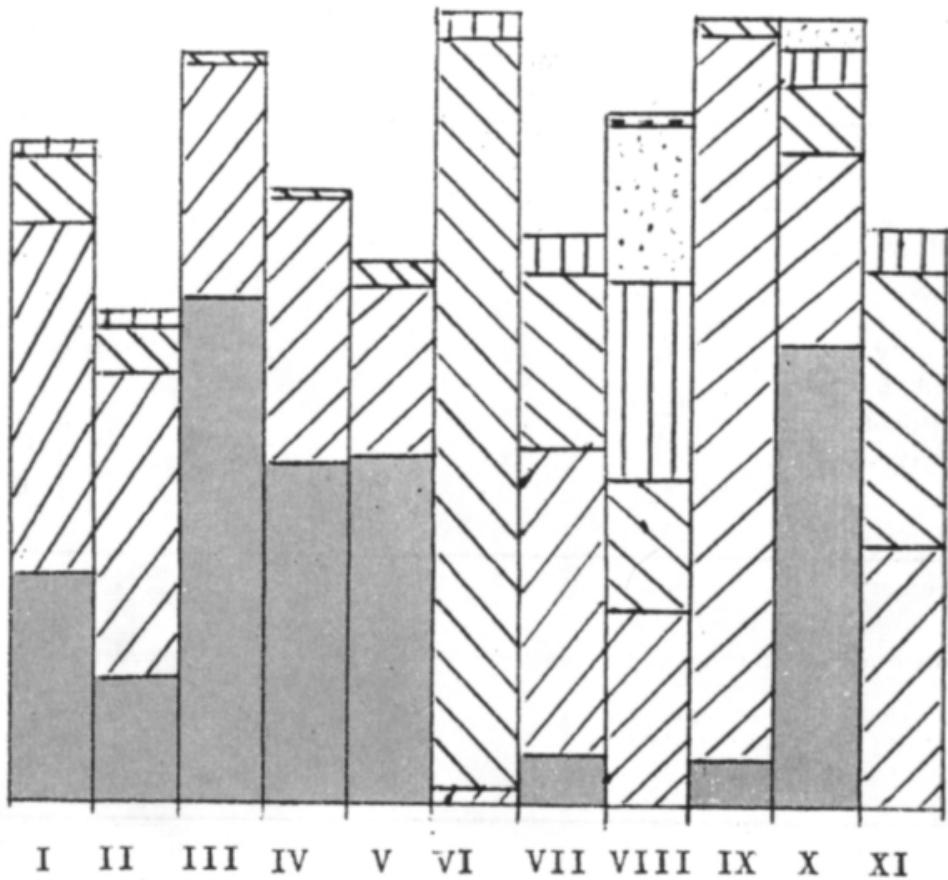

Figure 2. Rate of emergence of medium-sized seeds from $1-\mathrm{cm}$ depth. The eleven grassland plants I-XI listed under Material and methodss.

regard to the rate of emergence. Thus, for example, the tetraploid red (II) and alsike (IV) clovers obviously emerged more slowly than the corresponding diploids (I and III). Besides this, the total emergence of the tetraploids proved to be less than that of the diploid strains.

From Figure 2 it further appears that, among the grasses, the seeds of Italian rye-grass (X) began emerging with exceptional rapidity. In timothy (VI), cocksfoot 
(VIII), and red fescue (XI), on the other hand, no emergence occurred during the first three-day period. The rate of emergence of meadow fescue (VII) and perennial rye-grass (IX) was also slow at the outset.

Maximum emergence was usually reached from 9 to 12 days after seeding. The emergence of Italian rye-grass (X) was not complete until 15 days after seeding. In cocksfoot (VIII), total emergence was only attained in 18 days; the rate of emergence of this species was thus slowest in the category of medium-sized seeds sown at $1-\mathrm{cm}$ depth.

It was further established that rate of emergence was considerably retarded with increasing depth. As a result of deeper sowing, the time required for complete emergence was distinctly prolonged in many of the strains studied. Thus, for example,

Table 1. Average-seedling emergence from 100 seeds of eleven grassland plants of different weight Grassland Seed size Variation due plant to seed size

\begin{tabular}{|c|c|c|c|c|c|c|c|}
\hline & & \\
\hline & & Small & Med. & Large & Super & D.F. & $\mathrm{F}$ value \\
\hline I & Red clover, dipl. & 47 & 54 & 47 & - & 2 & 3.08 \\
\hline II & tetr. & 34 & 44 & 52 & 55 & 3 & $11.7^{* * *}$ \\
\hline III & Alsike cl., dipl. & 63 & 65 & 67 & - & 2 & 1.72 \\
\hline IV & tetr. & 53 & 55 & 61 & 64 & 3 & $7.2 * * *$ \\
\hline $\mathrm{v}$ & White clover & 40 & 51 & 57 & - & 2 & $44.0^{* * *}$ \\
\hline VI & Timothy & 40 & 54 & 57 & 71 & 3 & $1103.2^{* * *}$ \\
\hline VII & Mead. fescue & 44 & 49 & 65 & - & 2 & $23.9 * * *$ \\
\hline VIII & Cocksfoot & 57 & 55 & 62 & - & 2 & 2.19 \\
\hline IX & Per. rye-grass & 70 & 72 & 74 & - & 2 & 1.79 \\
\hline $\mathrm{x}$ & Ital. & 72 & 75 & 77 & - & 2 & $6.79 * *$ \\
\hline XI 1 & Red fescue & 51 & 57 & 56 & - & 2 & 1.97 \\
\hline Grand & d averag & 52 & 57 & 61 & 63 & - & - \\
\hline
\end{tabular}

classes sown at five depths, as well as the analyses of variance of seed size and depth of seeding Depth of seeding,
$\mathrm{cm}$

Variation due
to depth
of seeding

Size $\times$ depth interaction

\begin{tabular}{rrrrrrrrc}
\hline 0 & 1 & 2.5 & 4 & 7 & D.F. & F value & D.F. & F value \\
\hline 78 & 63 & 48 & 41 & 16 & 4 & $56.4^{* * *}$ & 8 & $3.44^{* *}$ \\
79 & 52 & 54 & 36 & 12 & 4 & $65.0^{* * *}$ & 12 & $2.85^{* *}$ \\
85 & 85 & 77 & 77 & 1 & 4 & $247.0^{* * *}$ & 8 & 1.14 \\
87 & 78 & 78 & 45 & 3 & 4 & $266.8^{* * *}$ & 12 & $2.55^{* * *}$ \\
64 & 64 & 62 & 54 & 1 & 4 & $283.0^{* * *}$ & 8 & $5.54^{* * *}$ \\
80 & 91 & 79 & 29 & 1 & 4 & $8372.6^{* * *}$ & 12 & $377.7 * * *$ \\
62 & 73 & 65 & 32 & 33 & 4 & $43.0^{* * *}$ & 8 & 0.54 \\
82 & 85 & 70 & 46 & 8 & 4 & $99.3^{* * *}$ & 8 & 1.07 \\
82 & 92 & 91 & 88 & 7 & 4 & $414.4^{* * *}$ & 8 & 0.71 \\
92 & 93 & 95 & 89 & 7 & 4 & $817.6^{* * *}$ & 8 & $3.34 * *$ \\
74 & 64 & 58 & 54 & 5 & 4 & $86.8^{* * *}$ & 8 & 0.96 \\
\hline 79 & 76 & 71 & 54 & 9 & - & - & - & -
\end{tabular}


the total emergence of meadow fescue (VII), perennial rye-grass (IX), and red fescue (XI) sown at 7-cm depth was not reached until 21 days after seeding, the corresponding times at $1-\mathrm{cm}$ depth being 12,9 , and 12 days.

The data on the average total emergence are shown in Table 1, which also contains the results of the corresponding analyses of variance. From the data thus presented, it is possible to gain an idea of the significance of seed size and of different depths of sowing on emergence capacity.

In the diploid red and alsike clover seed size proved to have no significant influence on the differences in emergence capacity. In the corresponding tetraploids, however, seed size proved to be highly significant. In four of the remaining seven species distinct dependence of total emergence upon seed size was established, too. These were: white clover, timothy, meadow fescue, and Italian rye-grass. In cocksfoot, perennial rye-grass and red fescue, on the other hand, no significant relationship was found.

As regards depth of seeding (Table 1), highly significant effects of this factor on the emergence capacity were established in all eleven strains investigated. The importance of depth of seeding thus appeared to be greater than that of seed size. The numbers of seedlings emerging from different depths show very considerable differences. In the tetraploid clovers, timothy, meadow fescue and cocksfoot, seeding $4 \mathrm{~cm}$ deep already markedly impaired emergence. At $7 \mathrm{~cm}$ the seedlings' chances of becoming established were appreciably weakened. The diploid and tetraploid alsike clover, white clover and timothy were the most sensitive in this respect. Of the eleven strains investigated only meadow fescue was able to emerge passably from a depth of $7 \mathrm{~cm}$.

In addition, statistical analysis of the data indicates significant interaction for the sizes $\mathrm{x}$ depths in four legumes and two grasses (Table 1). This result reveals that in these strains there are real differences in the emergence capacity of seedlings of various weight classes seeded at different depths. On the other hand, in one legume and four grasses no such interaction could be established with certainty.

\section{Discussion}

Because the moisture conditions in the dishes were continuously kept at optimal level, the emergence figures obtained in this experiment are obviously much higher than those found in natural conditions. This is especially true in the case of the surface seedings; seedlings situated on the soil surface in the field are more exposed to drought injury than those within the soil.

The legumes, in most cases, began emerging from 1-cm depth more rapidly than the grasses. Further, the legumes reached total emergence from this depth on an average three days before the grasses (Fig. 2). This result is in accordance with the findings of MURPHY and ARNY (4), who reported a similar relation between the rates of emergence of five legumes and five grasses. The rapid emergence of the legumes is an evident advantage. Thus, at the establishment of a ley the legumes are obviously in need of favourable conditions for emergence for a shorter period of time after seeding than the grasses. 
The emergence capacity of the tetraploid clovers (II and IV) seems to be weaker than that of the corresponding diploids (I and III); (Fig. 2 and Table 1). This finding, however, may not be generally applicable. Both the tetraploid clover strains investigated, Jo TPA 1 red clover and Jo TAA 4 alsike clover, are relatively newly produced strains that have obviously not yet reached complete physiological balance. It is to be expected, therefore, that as a result of continued breeding their emergence capacity will improve essentially.

Comparison of the influence of seed size and the depth of seeding on emergence (Table 1) reveals that the average emergence figures for the four seed-size classes differ from one another relatively little. Further, in five of the eleven strains studied, no significant dependence of total emergence upon seed size was found. The average emergence figures at different seeding depths, on the contrary, varied considerably. The effect upon emergence of the depth of seeding proved also to be highly significant in all strains.

The average figures of emergence from seedings made on the soil surface and at depths of 1 and $2.5 \mathrm{~cm}$ were about equally high (Table 1). Emergence from a depth of $4 \mathrm{~cm}$, on the other hand, was considerably lower than in the above-mentioned cases. Even so, on an average more than half of all the seeds of the different strains placed at a depth of $4 \mathrm{~cm}$, gave rise to emerging seedlings. The emergence from this depth of the diploid alsike clover and of the two rye-grasses may even be considered very satisfactory. Finally, seeding at $7-\mathrm{cm}$ depth gave rather poor emergence in all the strains examined, with the exception of meadow fescue.

Thus, under the conditions of this experiment, it appeared that $4 \mathrm{~cm}$ may be considered the maximum depth from which most of the strains studied are still able to give intermediate or satisfactory establishment (Table 1). The average emergence figures of the two most important grassland plants in Finnish leys, the diploid red clover and timothy, were markedly reduced at this depth of seeding, being 41 and 29 , respectively.

\section{Conclusions}

From 1-cm depth of seeding the legumes, on the whole, began to emerge more rapidly than the grass seedlings. Besides this, the legumes often attained total emergence over a shorter period of time than the grasses.

Between the rates of emergence of the individual strains some considerable differences were established. Maximum emergence from 1-cm depth was generally reached from 9 to 12 days after seeding.

The rate of emergence was considerably retarded at greater depths. Correspondingly, the time required for complete emergence was distinctly prolonged in many of the strains studied.

The influence of depth of seeding on the emergence of the eleven strains investigated proved to be greater than that of seed size. In four legumes and two grasses significant interaction for the sizes $\mathrm{x}$ depths was ascertained.

Under the conditions of the experiment, seeding at 4-cm depth may be considered the maximum depth of seeding for most of the strains investigated. 


\title{
REFERENCES
}

(1) Erickson, L. C. 1946. The effect of alfalfa seed size and depth of seeding upon the subsequent procurement of stand. J. Amer. Soc. Agron. 38: 964-973.

(2) Lueck, A. G. \& Sprague, V. G. \& Garber, R. J. 1949. The effects of a companion crop and depth of planting on the establishment of smooth bromegrass, Bromus inermis, Leyss. Agron. J. 41: $137-140$.

(3) Mc Kenzie, R. E. \& Heinrichs, D. H. \& Anderson, L. J. 1946. Maximum depth of seeding eight cultivated grasses. Scient. Agric. 26: 426-431.

(4) Murphy, R. P. \& Arny, A. C. 1939. The emergence of grass and legume seedlings planted at different depths in five soil types. J. Amer. Soc. Agron. 31: 17-28.

(5) Rogler, G. A. 1954. Seed size and seedling vigor in crested wheatgrass. Agron. J. 46: 216-220.

\section{SELOSTUS:}

\section{SIEMENEN KOON JA KYLVÖSYVYYDEN VAIKUTUS NURMIKASVIEN ORASTUMISEEN}

\author{
K. MUltamäKI
}

Maatalouden tutkimuskeskus, Kasvinjalostuslaitos, Jokioinen

Yhdentoista nurmikasvikannan siemenistä otettiin 3 tai 4 siemenkokolajitetta, jotka kylvettiin orastumisastiaan joko pintaan, 1, 2.5, 4 tai 7 senttimetrin syvyyteen (kuva 1). Orastumisalustana käytettiin laitoksen koekentăn muokkauskerroksesta otettua aitosavimaata. Kuhunkin astiaan kylvettiin 100 siementä. Erikokoisten siemenlajitteiden itämisprosentti vaihteli $96-100$.

Pyrittäessä vertailemaan eri kantojen orastumisnopeutta laskettiin yhden senttimetrin syvyyteen kylvettyjen keskikokoisten siementen orastumisluvut kolmipäiväisille ajanjaksoille (kuva 2). Nurmipalkokasvien $(\mathrm{I}-\mathrm{V})$ siementaimet alkoivat yleensä orastua nopeammin kuin heinien (VI-XI) ja ne orastuivat keskimäärin kolme päivää lyhyemmässä ajassa kuin viimeksi mainitut. Tetraploidiset apilat (II ja IV) orastuivat hitaammin ja heikommin kuin vastaavat diploidit (I ja III). Tämã johtunee kuitenkin siitä, että kokeillut tetraploidiset kannat ovat keskeneräisiä jalosteita, joiden fysiologinen tasapaino ei vielä liene täysin vakiintunut.

Yhden senttimetrin syvyyteen kylvetyt siemenet ehtivăt yleensä orastua täysin $9-12$ päivässã. Italialaisella raiheinällä (X), joka aloitti orastumisensa erittäin nopeasti, kului täydelliseen orastumiseen aikaa 15 päiväa. Koiranheinä (VIII) orastui yhden senttimetrin syvyydestä täysin vasta 18 păivä̀n kuluttua.

Kylvösyvyyden kasvaessa orastumisnopeus hidastui. Tästä johtuen lisääntyi useiden kantojen täydelliseen orastumiseen tarvittava aika tuntuvasti.

Erikokoisten ja eri syvyyteen kylvettyjen siemenien keskimääräisten orastumisprosenttien (taulukko 1) nojalla on päăteltävissä, että kylvösyvyydellä on tärkeämpi merkitys orastumiselle kuin siemenen koolla. Neljässä nurmipalkokasvissa ja kahdessa heinässä todettiin siemenen koon ja kylvősyvyyden välillä tilastollisesti merkitsevä vuorovaikutus.

Kokeillussa aitosavimaassa voitaneen neljää senttimetriä pitää maksimisyvyytenä, josta useimmat tutkitut kannat pystyivät vielä orastumaan keskinkertaisesti tai tyydyttävästi (taulukko 1). Kahden tärkeimmän nurmikasvimme, diploidisen puna-apilan sekä timotein orastuminen tästä syvyydestä oli jo tuntuvasti vaikeutunut. 